\title{
The Impact Of The Loss Of Wheat To Agricultural Resources And Food Security Of The Kingdom Of Saudi Arabia
}

\author{
Khaled N.Alrwis, \\ Sharaf A. Bakri Ahamad
}

Adel M. Ghamen, Nageeb M. Ali Aldawdahi

King Abdullah Ben Abdulaziz Food Security Chair, King Saud University, College of food and Agricultural Sciences,Agricultural economics, PO Box 2460,Riyadh 11451.

\begin{abstract}
This research aimed to identify the economic dimension of the loss of wheat and how it relates to loss in agricultural resources and food security in Saudi Arabia during 1990-2014. This study attempted to achieve its objectives using economic equations and economic analysis standards. Results of this study showed the following: (a) increased losses of wheat at an average annual growth rate of $1.24 \%$ until the losses reached 88.02 thousand tons in 2014; (b) an increase in the loss ratio to local wheat production at an average annual growth rate of $6.03 \%$; (c) a decrease in the loss ratio to domestic consumption of wheat at an average annual decrease of $0.98 \%$; (d) a social loss of 139.98 million riyals in 2014 as a result of the loss of land resources, agricultural water, labour, and chemical fertilizers; and (e) an increase in the periods adequacy of production and to cover imports for domestic consumption by $10 \%$ lead to increased food security for wheat at $13.9 \%$ and $3.3 \%$ each, respectively, while an increase in the size of losses for wheat by $10 \%$ leads to a decrease in food security for wheat by $75.6 \%$.
\end{abstract}

Keywords: Agricultural resources, Food security, Losses, Nutrition food, Saudi Arabia, Wheat.

\section{Introduction}

Arab countries paid attention to standard specifications which trade in goods and agricultural products motion controller, in addition to interest in the establishment and development of government agencies to emphasize the quality of various commodities in order to reduce waste and enhance the competitive forces of Arab agricultural products over imported counterparts and to create markets for Arab agricultural products, especially in light of economic changes and developments the world has witnessed after the liberalization of international trade (Al-Najjar, 2002). Most of the marketing operations of goods and traditional methods can result in increased losses, and any loss as a result of increased social loss in agricultural resources contributes to the production of the equivalent of the missing quantities of food commodities. Because of the spread of the phenomenon of extravagance and wasteful loss of consumer food in Saudi Arabia has increased until it reached $250 \mathrm{~kg} /$ capita per year (Ministry of Agriculture, 2015), indicating the presence of large amounts of food not being used, especially in urban areas where the proportion of consumer waste is about $34 \%$, which affects the level of food security for the most important strategic goods. 


\section{Research objectives}

This research aimed to identify the economic dimension of the loss of wheat and how that loss relates to agricultural resources and food security in Saudi Arabia from 1990 to 2014, through the study of the following objectives:

- The evolution of the volume of the loss attributed to the production and domestic consumption of wheat.

- An estimation of the social loss resulting from the loss of agricultural resources used in the production of an equivalent amount of losses of wheat.

- An estimation of the impact of losses of wheat on the level of food security for wheat during the study period.

\section{Study methodology}

This research adopted standard economic analysis techniques, specifically the use of the following equations and models:

- Economic equations to estimate the loss in agricultural resources (land, labour, water, and chemical fertilizers) used in the production of an equivalent loss of wheat. These equations (Kamra, 2008) measure (a) the amount of loss in the earth's resources $=$ (the amount of waste $\div$ average productivity per hectare) and (b) the amount of loss in water resources and chemical fertilizers $=[($ losses amount $\times$ resources need $) \div$ average hectare productivity].

- A proposed model to study the impact of the loss of wheat on the level of food security from 1990 to 2014. The proposed model consists of four behavioural equations:

$$
\begin{aligned}
& \hat{\mathbf{Y}}_{1}=a_{0}+a_{1} \mathbf{X}_{1}+a_{2} X_{2}+z_{1} \\
& \hat{\mathbf{Y}}_{z}=b_{0}+b_{1} X_{2}+b_{2} \mathbf{X}_{3}+z_{2} \\
& \hat{\mathbf{Y}}_{3}=c_{0}+a_{1} X_{2}+a_{3} \\
& \hat{\mathbf{Y}}_{4}=d_{0}+d_{1} \hat{Y}_{1}+d_{2} \hat{\mathbf{Y}}_{2}+d_{2} \hat{\mathbf{Y}}_{3}+e_{4}
\end{aligned}
$$

The proposed model includes endogenous and exogenous variables. Endogenous variables are four variables represented in both the adequacy of production for the local consumption day period ( $\left.\hat{\mathbf{Y}}_{\mathbf{1}}\right)$, cover imports for the local consumption day period $\left(\hat{\mathbf{Y}}_{\mathbf{z}}\right)$, the amount of losses of wheat per thousand tons $\left(\hat{\mathbf{Y}}_{\mathbf{z}}\right)$, and the coefficient of food security expressed in the deficit to the annual domestic consumption by the amount of surplus $\left(\hat{\mathbf{V}}_{\mathbf{4}}\right)$.

Exogenous variables are three variables represented in the domestic production in thousand tons $\left(\mathrm{X}_{z}\right)$, domestic consumption in thousand tons $\left(\mathrm{X}_{z}\right)$, and the amount of Saudi imports of wheat per thousand tons $\left(\mathbf{x}_{\mathbf{z}}\right)$, in addition to random errors $\left(e_{1}, e_{2}, e_{3}, z_{4}\right)$.

We used discrimination behavioural equations contained in the structural form of the proposed model by applying the requirement rank order condition and rank condition. The total number of internal and external variables of the proposed model (k) minus the number of internal and external variables given by the subject of the definition (L) is greater than the number of internal variables (M) minus one, that is, $(\mathrm{K}-\mathrm{L})>(\mathrm{M}-1)$. The equations behavioural check condition order and rank condition 
which redundant equations over-identified, with the exception of the fourth equation, are exactly the characteristic equation, which means it is possible to use the method of two-stage least squares (2SLS) in the estimation of the proposed model. The least squares method can be applied with phases according to the following steps (Makridakis, Wheelwright, \& McGee, 2003): (a) conducting regression model for endogenous variables on each of the specific variables in advance in the reduced form and (b) estimating the relationship between the dependent variable in each equation and the estimated values of the explanatory variables of the interior, as well as other external variables that contain them and the structural form equations.

\section{Previous studies}

Some studies have addressed the economic losses and food. Kamra (2008) studied the impact of post-harvest technology to the losses of the most important fruit and vegetables on the market and how that relates to social loss or loss in agricultural economic resources in Alexandria. It emerged from this study that the value of social loss as a result of the loss of land resources, agricultural labour, water resources, and chemical fertilizers amounted to about a million pounds, and thus became the marketing policy of the most important fruit and vegetables to reduce the natural risk (market loss).

Bdour (2010) estimated the post-harvest losses for some vegetable crops in Jordan. The study found that the proportion of losses at the farm level and wholesaler and retailer of cucumbers, peppers, beans, and tomatoes amounted to about $25 \%$, $23.9 \%, 23 \%$, and $22 \%$, respectively. The higher loss was attributed to lack of interest in Jordanian farm technology, and post-harvest operations for cooling, washing, sorting, and grading.

The Arab Organization for Agricultural Development report (2012) on the Arab food security situation found that post-harvest losses to the Arab production rate ranged from a minimum of $9.8 \%$ for legumes and a maximum of $17.5 \%$ for vegetables. This study recommended reducing food waste by raising awareness among producers and consumers; developing storage infrastructure, transport, and refrigeration; developing marketing services and systems market information; and raising food manufacturing efficiency.

Finally, the Food and Agriculture Organization report (2013) explained that the amount of food wasted every year amounts to 1.3 billion tons, with a direct economic cost of 750 billion dollar. There is no doubt that food waste not only leads to huge economic losses, but also to serious damage to the natural and human resources that depends on this food. In addition, food that is produced but not consumed every year swallows a quantity of water comparable to the annual flow of the River Volga in Russia, It also adds about 3.3 billion tons of greenhouse gasses to the atmosphere of the planet.

It is clear that some of the previous studies dealt with the loss and how it relates to the marketing of loss in agricultural resources, while other research studied food waste and its impact on natural resources and the environment. These studies, however, neglected the impact of commodity losses on the level of food security, which is what this study sought to do. 
And Food Security Of The Kingdom Of Saudi Arabia

\section{Research results}

5.1 The evolution of losses attributed to the production and domestic consumption of wheat

Studying the evolution of losses attributed to the production and domestic consumption of wheat during the period 1990-2014, it is clear from the data in Table (1) losses of wheat ranged from a minimum of 26.00 thousand tons in 1996 and reached a high of 88.02 thousand tons in 2014, with an annual average loss of about 53.09 thousand tons. The loss of wheat increased annually at a rate of $1.24 \%$ during the study period. The loss rate for local production of wheat ranged from a minimum of $1.68 \%$ during the period 2000-2002 and amounted to a high of $15.24 \%$ in 2014 , with an annual average rate of $3.48 \%$ during the study period. The loss ratio to the local production of wheat increased at an average annual rate of $6.03 \%$ annually during the study period. Losses to domestic consumption of wheat ranged from a minimum of $1.47 \%$ in 1998 to a high of $3.39 \%$ in $1993-1994$, with an annual average of $2.25 \%$ during the study period. The loss ratio to the domestic consumption of wheat fell to $0.98 \%$ annually during the study period.

Table (1): Statistical analysis of the evolution of the losses attributed to the production and domestic consumption of wheat during the period 1990-2014.

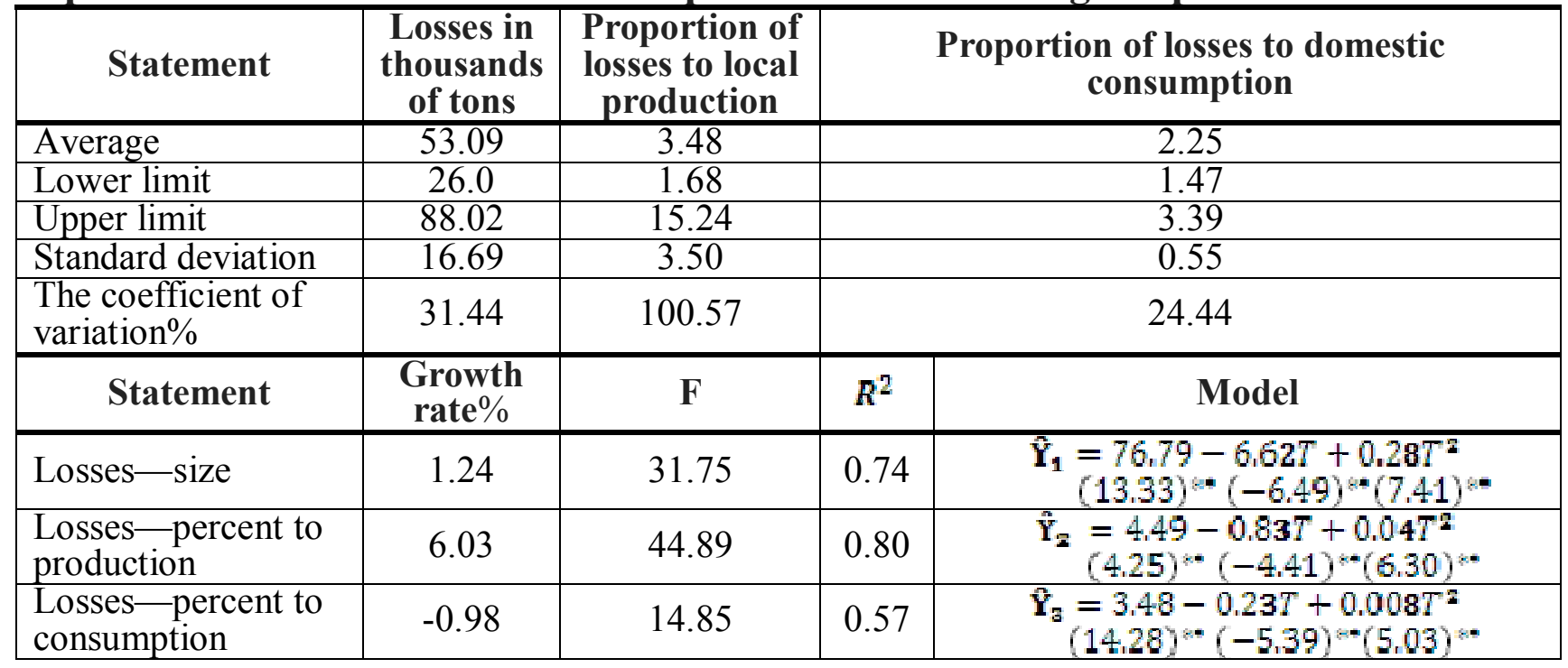

** Significant at the level of $1 \%$ probability.

Source: Collected and calculated from Ministry of Agriculture, Studies and Statistics Department. Annual Agricultural Statistical Yearbook, various issues, the period 19902014 and the Food and Agriculture Organization (FAO), the period 1990 to 2011.

\subsection{Losses in agricultural resources used in the production of the equivalent of the loss of wheat}

Data in Table (2) show that the amount of loss in agricultural resources in the light of the resources needed and the amount of losses of wheat was calculated to be a loss in the earth's resources of 13.69 thousand hectares. With an average rental value for a wheat season of 2.5 thousand riyals production per hectare, the loss in the value of the land resources amounted to 34.22 million riyals. The loss in water resources reached a total of 109.51 million $\mathrm{m}^{3}$. With the average cost per unit of water used for agricultural purposes amounting to 0.622 riyals per $\mathrm{m}^{3}$, the water loss was calculated to be 68.12 million riyals. 
$\Lambda \vee$.

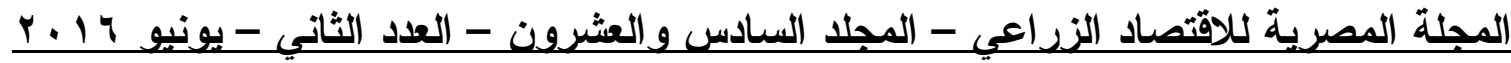

In agricultural employment, the loss amounted to about 342.22 thousand per man per day. With a worker's average wage of 75 riyals per day, the loss in the value of agricultural employment was 25.67 million riyals. Finally, the amount of chemical fertilizers involved in the loss was about 4.79 million tons and the average retail price of chemical fertilizers was 2.5 riyal per kilogram, making the loss in value of chemical fertilizers 11.98 million riyals.

Based on these data points, it is clear that the value of social losses resulting in the loss of agricultural land resources, labour, water, and chemical fertilizers amounted to 139.98 million riyals in 2014 .

Table (2): Resource needs, size of losses for wheat, and equivalent loss of agricultural resources in 2014.

\begin{tabular}{|c|c|c|c|}
\hline Statement & Quantity & Resources prices & $\begin{array}{c}\text { Value in million } \\
\text { riyals }\end{array}$ \\
\hline Losses-quantity & & 8.02 thousand tons & \\
\hline \multicolumn{4}{|c|}{$\begin{array}{l}88.02 \text { thousand tons } \\
\text { Resources needs per hectare: }\end{array}$} \\
\hline Labour man/day & \multicolumn{3}{|c|}{25} \\
\hline Water(million $\mathrm{m}^{3}$ ) & \multicolumn{3}{|c|}{8.0} \\
\hline $\begin{array}{l}\text { Chemical } \\
\text { fertilizers }(\mathrm{kg} / \text { hectare) }\end{array}$ & \multicolumn{3}{|c|}{350} \\
\hline Hectare( productivity) & \multicolumn{3}{|c|}{6.43} \\
\hline \multicolumn{4}{|c|}{ Amount of loss in agricultural resources } \\
\hline Land(thousands hectare) & 13.69 & 2,500 riyals/hectare & 34.22 \\
\hline Labour man/day & 342.22 & 75 riyals/day & 25.67 \\
\hline Water(million $\left.\mathrm{m}^{3}\right)$ & 109.51 & 0.622 riyals $/ \mathrm{m}^{3}$ & 68.12 \\
\hline $\begin{array}{l}\text { Chemical fertilizers } \\
\text { (thousands ton) }\end{array}$ & 4.79 & 2.525 riyals $/ \mathrm{kg}$ & 11.98 \\
\hline Total & - & - & 139.98 \\
\hline
\end{tabular}

Source: Collected and calculated from data in Table (1) and from Qunaibet and Ghanem, 2015.

\subsection{The impact of losses on food security level for wheat}

The impact of losses on food security for wheat was measured by estimating the reduced form equations and proposed structural model of a two-stage least squares (2SLS) method. Tables (3) and (4) show that increasing the domestic production of wheat $\left(X_{1}\right)$ by $10 \%$ led to an increase in the production adequacy for local consumption period by $9.4 \%$. The data also show that an increase in the domestic consumption of wheat $\left(X_{\boldsymbol{z}}\right)$ by $10 \%$ led to diminishing production adequacy period and imports coverage for local consumption by $9.7 \%$ and $9.6 \%$, respectively.

Further, an increase in the amount of Saudi imports of wheat $\left(X_{a}\right)$ of $10 \%$ led to an increase in the coverage of imports for local consumption by $9.9 \%$. An increase in the domestic consumption of wheat $\left(X_{2}\right)$ in light of the spread of the phenomenon of extravagance and social customs erroneously led to increased losses of wheat by $2 \%$; an increase in the production adequacy period to cover imports for local consumption by $10 \%$ led to increased food security for wheat by $13.9 \%$ and $3.3 \%$, respectively; and an increase in the size of losses for wheat by $10 \%$ led to a decrease in food security for wheat by $75.6 \%$.

Statistical tests show that the equations in the proposed model in Table (4) are free from any autocorrelation of residuals problems, where the $\mathrm{F}$ value to BreuschGodfrey serial correlation LM test ranged from a minimum of 0.08 and a maximum of 0.67 , which are not statistically significant at the $1 \%$ probability level. 


\section{And Food Security Of The Kingdom Of Saudi Arabia}

Table (3): The reduced form equations of the model proposed during the period 1990-2014.

\begin{tabular}{|c|c|c|c|c|}
\hline $\begin{array}{l}\text { Level of food } \\
\text { security } \\
\ln \overrightarrow{\mathrm{Y}}_{4}\end{array}$ & $\begin{array}{c}\text { Wheat losses } \\
\operatorname{Ln}_{\mathbb{Y}_{3}}\end{array}$ & $\begin{array}{c}\text { Period of } \\
\text { imports coverage } \\
\text { to consumption } \\
\operatorname{Ln}_{\hat{\mathrm{Y}}} \\
\end{array}$ & $\begin{array}{c}\text { Production adequacy } \\
\text { period for } \\
\text { consumption } \\
\operatorname{Ln} \hat{\mathrm{Y}}_{1}\end{array}$ & Statement \\
\hline $\begin{array}{r}22.31 \\
(1.14)^{n z}\end{array}$ & $\begin{array}{c}-2.69 \\
(-0.71)^{n s}\end{array}$ & $\begin{array}{c}5.32 \\
(3.78)^{*}\end{array}$ & $\begin{array}{c}5.89 \\
(2060.99)^{-}\end{array}$ & $\mathrm{a}$ \\
\hline $\begin{array}{c}0.73 \\
(2.25)^{-}\end{array}$ & $\begin{array}{c}0.70 \\
(4.94)\end{array}$ & $\begin{array}{c}0.004 \\
(0.12)^{n=}\end{array}$ & $\begin{array}{c}0.93 \\
(12580.79)^{*}\end{array}$ & $\operatorname{Ln} X_{1}$ \\
\hline $\begin{array}{c}-2.58 \\
(-2.93)=\end{array}$ & $\begin{array}{c}0.20 \\
(2.07)^{-}\end{array}$ & $\begin{array}{c}-0.96 \\
(-14.54)^{\circ}\end{array}$ & $\begin{array}{c}-0.99 \\
(-724781)^{\circ}\end{array}$ & $\ln X_{z}$ \\
\hline $\begin{array}{c}0.26 \\
(4.27)^{*}\end{array}$ & $\begin{array}{l}-0.0008 \\
(-3.05)^{-=}\end{array}$ & $\begin{array}{c}0.99 \\
(178.68)^{\div *}\end{array}$ & $\begin{array}{l}-0.00002 \\
(-1.96)^{*}\end{array}$ & $\operatorname{Ln} X_{3}$ \\
\hline- & $\begin{array}{c}1.16 \\
(13.45)^{-}\end{array}$ & - & - & $\operatorname{Ar}(1)$ \\
\hline 0.72 & 0.82 & 0.95 & 0.98 & $R^{2}$ \\
\hline 11.97 & 21.33 & 13906.95 & $2.42 \mathrm{E}+08$ & $\mathrm{~F}$ \\
\hline 1.52 & 2.12 & 2.13 & 2.68 & D.W. \\
\hline 0.72 & 0.05 & 0.26 & 1.96 & LM test \\
\hline
\end{tabular}

** Significant at the level of $1 \%$ probability. Not significant

Source: collected and calculated from the Ministry of Agriculture, Studies and Statistics Department. Annual Agricultural Statistical Yearbook, various issues, 1990-2014, and the Food and Agriculture Organization (FAO), 1990-2011.

Table (4): The structural equations of the proposed format of the model during the period 1990-2014.

\begin{tabular}{|c|c|c|c|c|}
\hline Statement & $\begin{array}{c}\text { Production adequacy } \\
\text { period for } \\
\text { consumption } \\
\operatorname{Ln} \mathrm{Y}_{3} \\
\end{array}$ & $\begin{array}{c}\text { Period of imports } \\
\text { coverage to } \\
\text { consumption } \\
\operatorname{Ln} \mathbf{Y}_{2} \\
\end{array}$ & $\begin{array}{c}\text { Wheat losses } \\
\operatorname{Ln} \tilde{\mathbf{Y}}_{3}\end{array}$ & $\begin{array}{l}\text { Level of } \\
\text { food } \\
\text { security } \\
\operatorname{Ln}_{n} \hat{Y}_{4} \\
\end{array}$ \\
\hline $\bar{a}$ & $\begin{array}{c}5.81 \\
(1965.05)^{\circ *} \\
\end{array}$ & $\begin{array}{c}5.46 \\
(7,80)^{\circ} \\
\end{array}$ & $\begin{array}{c}7.88 \\
(2.05)^{-}\end{array}$ & $\begin{array}{l}71.92 \\
(2.11)^{-}\end{array}$ \\
\hline $\operatorname{Ln} X_{1}$ & $\begin{array}{c}0.94 \\
(11968.03)^{*}\end{array}$ & $\begin{array}{c}-0.96 \\
(-19.41)^{\prime}\end{array}$ & - & - \\
\hline $\ln X_{2}$ & $\begin{array}{c}-0.97 \\
(-7197.32)^{* *}\end{array}$ & - & $\begin{array}{c}0.20 \\
(2.78)^{*}\end{array}$ & - \\
\hline $\ln X_{0}$ & - & $\begin{array}{c}0.99 \\
(190.71)^{*}\end{array}$ & - & - \\
\hline $\operatorname{Ar}(1)$ & - & - & $\begin{array}{c}0.81 \\
(5.89)^{*}\end{array}$ & - \\
\hline $\operatorname{Ln} \hat{\mathbf{Y}}_{1}$ & - & - & - & $\begin{array}{c}1.39 \\
(4.63)^{-}\end{array}$ \\
\hline $\ln \hat{Y}_{2}$ & - & - & - & $\begin{array}{c}0.33 \\
(4.05)^{-=}\end{array}$ \\
\hline $\ln \hat{\mathbf{Y}}_{\mathrm{g}}$ & - & - & - & $\begin{array}{c}-7.56 \\
(-2.27)^{*}\end{array}$ \\
\hline$\pi^{2}$ & 0.95 & 0.91 & 0.67 & 0.70 \\
\hline $\mathrm{F}$ & $3.24 \mathrm{E}+08$ & 21941.24 & 20.93 & 9.92 \\
\hline D.W. & 2.31 & 2.13 & 1.83 & 1.24 \\
\hline LM test & 0.67 & 0.22 & 0.28 & 0.08 \\
\hline
\end{tabular}

** Significant at the level of $1 \%$ probability:

Source: Collected and calculated from reduced equations form of growth-Ministry of Agriculture, Studies and Statistics Department, Annual Agriculture Statistical Yearbook, various issues, 1990-2014, and the Food and Agriculture Organization (FAO), 1990-2011. 
Table (5) shows that the behavioural equations in the proposed model present good efficiency in the data used to estimate the representation, according to indicators including the Theil inequality coefficient (U-Theil), which approached a zero value.

These data indicate that food losses of wheat lead to a social loss from the loss in agricultural resources and a reduction in food security, in addition to pollution of the environment. We therefore recommend reducing food losses by: (a) expanding the use of technology after the harvest, (b) not requiring the non-use of agricultural resources in the production of food, (c) reusing food in the context of human consumption chains by targeting secondary markets or donating additional food to charities, social groups, and the poor, (d) converting food waste to feed for cattle if it is not suitable for human consumption, and (e) recycling food waste to produce compost.

Table (5): The efficiency of the reduced form equations and structural model of the proposed indicators during the period from 1990 to 2014

\begin{tabular}{|c|c|c|c|c|}
\hline \multicolumn{4}{|c|}{ Reduced equations form } & \multirow{2}{*}{ Indicator } \\
\hline Fourth & Third & Second & First & \\
\hline 0.71 & 3.25 & 0.06 & 0.0001 & R.M.S.E. \\
\hline 0.58 & 2.38 & 0.03 & 0.00008 & M.A.E. \\
\hline 23.29 & 21.71 & 3.22 & 0.001 & M.A.P.E. \\
\hline 0.15 & 0.13 & 0.009 & 0.0001 & (U) Theil \\
\hline \multicolumn{4}{|c|}{ Structural shape equations } & Indicator \\
\hline 0.72 & 0.31 & 0.06 & 0.0001 & R.M.S.E. \\
\hline 0.59 & 0.24 & 0.03 & 0.0001 & M.A.E. \\
\hline 7.46 & 2.30 & 3.21 & 0.002 & M.A.P.E. \\
\hline 0.15 & 0.01 & 0.009 & 0.00001 & (U) Theil \\
\hline
\end{tabular}

Source: Collected and calculated from reduced and structural form equations model contained in Tables (3) and (4).

6. Acknowledgement: This project was full financially supported by King Saud University, through Vice Deanship of Research Chairs.

\section{References}

Al-Najjar, Ahlam. (2002). Coordinate standards for goods and agricultural products, raw and semi-processed to serve the Greater Arab Free Trade Area. League of Arab States, the Arab Organization for Agricultural Development, Cairo.

Arab Organization for Agricultural Development. (2012). Arab food security situation. Khartoum.

Bdour, Muhammad Ali. (2010). Estimating post-harvest losses for some vegetable crops in Jordan. Jordan Journal of Agricultural Science, Vol. 6, No. 1, pp: 9198.

Food and Agriculture Organization. (2013). Food losses footprint impacts on natural resources. Rome (available at http://www.fao.org/nr/sustainability.

Kamra, Sahar Abdelmoneim. (2008). Technical impact on the post-harvest losses of agricultural marketing and economic resources to the most important fruits and vegetables produced in Alexandria, Mansoura. University Journal of 


\section{And Food Security Of The Kingdom Of Saudi Arabia}

Agricultural Sciences, Faculty of Agriculture, Mansoura University, Vol. 33, No. 5, May.

Makridakis, Spyros G.; Wheelwright, Steven C.; \& McGee, Victor E. (1993). Forecasting methods and application. 2nd ed. New York: John Wiley and Sons. Ministry of Agriculture, Studies and Statistics Department. Annual Agricultural Statistical Yearbook, various issues, the period 1990- 2014 AD.

Ministry of Agriculture. (2015). Agriculture calls for consumers to reduce their waste, food waste, the economic newspaper, September 30.

Qunaibet, Mohammed bin Hamad \& Ghanem, Adel Mohammed Khalifa. (2015). The most important resources used in the production of wheat in Riyadh pricing. Egyptian Journal of Agricultural Economics, Vol. 25, No. 4.

أثر الفاقد للقمح على الموارد الزراعية والأمن الغذائي للمملكة العربية السعودية

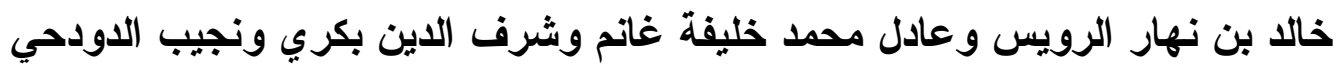

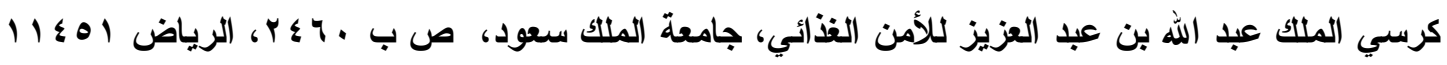

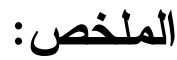

استهدف هذا البحث التعرف على البعد الإقتصادي للفاقد ومدى ارتباطه بالفقد في الموارد الزراعية

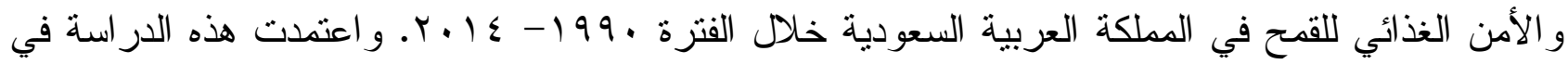

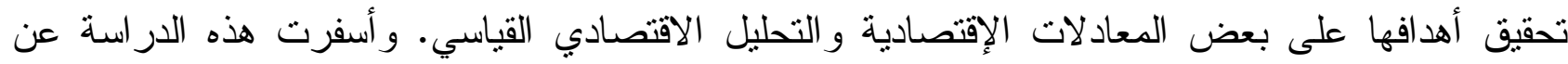

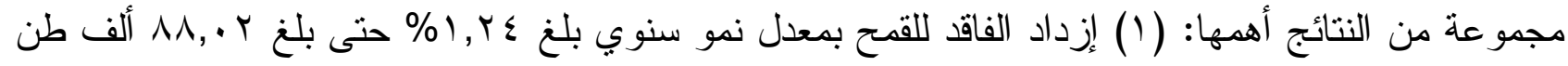

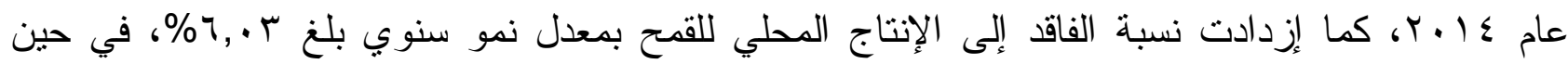

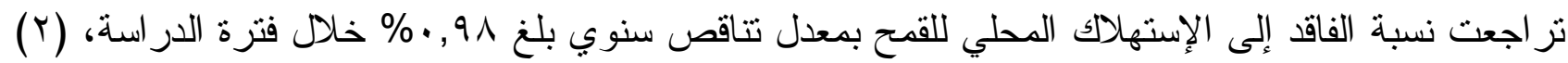

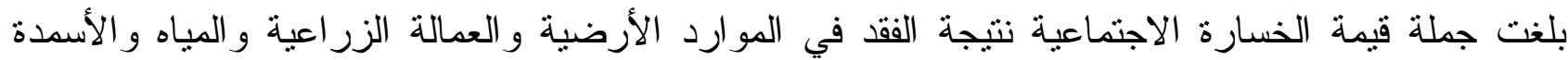





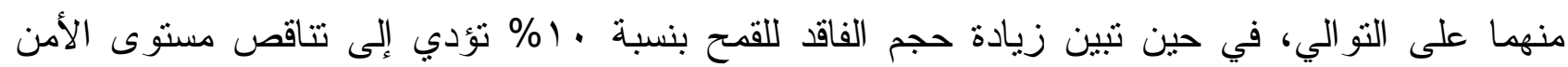

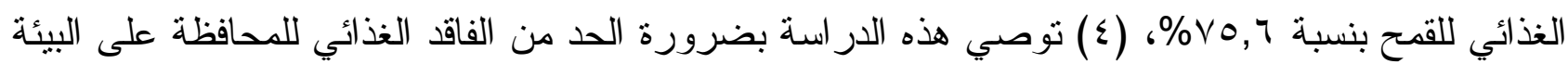

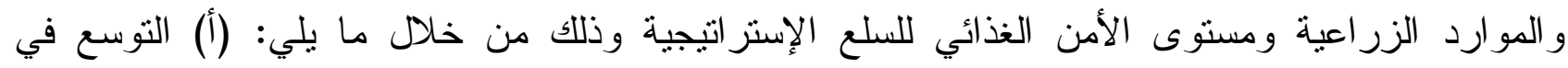

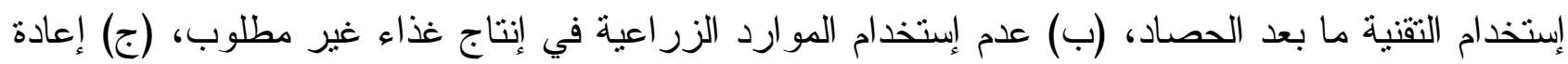

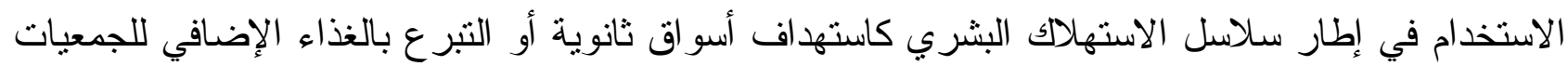

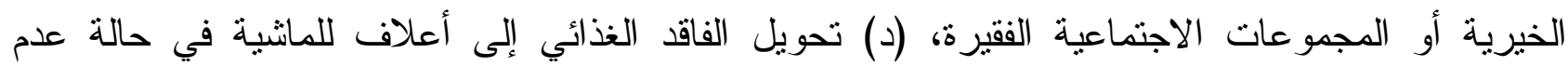



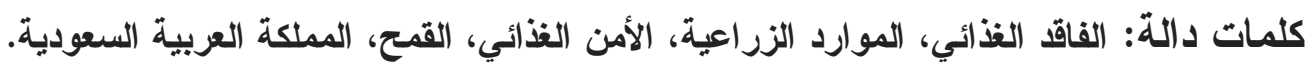

